\title{
THE ROLE OF NITRIC OXIDE IN ACUTE LUNG INJURY : A HISTOLOGICAL AND BIOCHEMICAL STUDY
}

\author{
Mohamed Mohamed EI Wasseef and * Dina Mohamed Radwan \\ Department of Anaesthesia and Intensive care. National Cancer Institute, \\ Cairo University. ${ }^{*}$ Histology Department, Faculty of Medicine, Cairo University
}

\section{INTRODUCTION}

Acute lung injury (ALI) is a disease characterized by an early phase of diffuse and severe inflammatory reaction of the lung parenchyma with loss of compartmentalization followed by a late fibroproliferative phase with fever (without a source of infection) and inability to improve the lung function (Meduri et al., 1995).

It remains an important contributor to the morbidity and mortality of patients in intensive care units throughout the world (Bernard et al., 1994). The most common causes are infection, sepsis, aspiration and trauma. Since trials of anti-inflammatory therapies in ALI have shown little benefit the exact mechanism by which the lungs are injured remains controversial (Numata et al., 1998).

Recent investigations suggested that nitric oxide (NO) may play a role in acute lung injury, both beneficial and detrimental roles have been proposed (Koristof et al., 1998 and Matsuo, 1999).

Nitric oxide (NO) is a highly reactive radical synthesized from the amino acid L-arginine by the action of nitric oxide synthases (NOS) (Palmer et al., 1987). Several isoforms of NOS have been identified and divided into two categories with different regulation and activities (Moncada et al., 1991).

The constitutive NOS (c-NOS) which exits in endothelial and neuronal cells and comprises the low output path on demand in homeostatic processes such as neurotransmission or blood pressure regulation (Lowestein et al., 1994). In addition, there are inducible isoforms (i-NOS) that may be expressed after exposore to endotoxin and certain cytokines (IL-1, TNF) in macrophages, mast cells, neutrophils and endothelial cells (Gelleret et al., 1993). 
Induction of $\mathrm{i}-\mathrm{NOS}$ is a much greater stimulus of NO production than activation of c-NOS (Beckman et al., 1992). Under physiologic states, NO may serve a protective function by scavenging superoxide to protect lung tissues, but the excessive production of NO may contribute to lissue damage in which NO reacts with superoxide to form peroxynitrite, a strong oxidant. It is suggested that peroxynitrite is an important oxidant in various tissues (Ischiropoulos et al., 1992).

So, this study was conducted to evaluate the effects of either increased or decreased endogenous production of nitric oxide on the pathophysiological course of endotoxacmia-induced acute lung injury using histological and biochemical methods.

\section{MATERIALS AND METHODS}

An animal model of endotoxaemia-induced lung injury was prepared then either the nitric oxide substrate or the nitric oxide synthase inhibitor was uscd.

\section{Drugs used :}

1. Caerulein sulfated : (Sigma chemical Co.)

It is an analogue of cholecystokinin used to prepare endotoxaemia-induced lung injury.

It is white powder, dissolved in gelatin (16\% w/v) to prolong its absorption. Given at dose $12 \mathrm{ug} / \mathrm{kg}$ every 8 hours for 2 days (Frossard et al., 2002).

\section{L-arginine free base : (Sigma chemical Co.)}

It is the substrate of nitric oxide synthesis i.e. nitric oxide donor. Given at dose $200 \mathrm{mg} / \mathrm{kg}$ every 8 hours for 2 days (Andrzejewska and Jurkowska, 1999).

3. N-G-Nitro - L-arginine (L-NNA) : (Sigma chemical Co.)

It is NOS inhibitor. Given at dose $10 \mathrm{mg} / \mathrm{kg}$ every 8 hours for 2 days (Andrzejewska and Jurkowska, 1999).

\section{B) Animals :}

Thirty two adult male albino rats were used. Their weights ranged between 170 - 200 grams. They were kept under hygienic conditions, fed ad libitum and allowed free water supply. Animals were divided into four equal groups. Each group was kept in a separate cage. 


\section{Group I :}

Received subcutancous saline injections in the same way as the experimental animals and served as control.

\section{Group II :}

Received cacrulcin subcutaneous injections for two days.

\section{Group III :}

Received subcutaneous injections of Caerulein and L-arginine for two days.

\section{Group IV :}

Received subcutaneous injections of Caerulein and L-NNA for two days.

The experiment was terminated five days after the last injection, coinciding with the end of early phase of acute lung injury (Anderson and Thielen, 1992) by sacrifaction of animals under chloroform anaesthesia.

\section{Methods :}

\section{A) Pulmonary gas exchange :}

The partial pressures of oxygen $\left(\mathrm{PaO}_{2}\right)$ and carbon dioxide $\left(\mathrm{PaCO}_{2}\right)$ and $\mathrm{pH}$ of arterial blood were measured just before sacrifaction using a blood gas analyzer (Radio meter ABL 520 Copenhagen) (Numata et al., 1998).

The mean values of all data of the studied groups were calculated and statistically compared using Duncan test (Mould, 1989).

\section{B) Histological study :}

Specimens from both lungs of all groups were fixed in $10 \%$ formol saline, then processed for paraffin blocks. Sections were cut at $5 \mu \mathrm{m}$ thickness. They were stained by $\mathrm{HX} / \mathrm{E}$ and subjected for immunostaining using the polyclonal inducible nitric oxide (i-NOS) antibodies.

\section{Immunostaining for inducible nitric oxide synthase (i-NOS) :}

It was carried out by Avidin-Biotin complex ( $A B C$ ). The primary antibody used was rabbit polyclonal antibody (from Lab vision NeoMarkers). Antigen retrieval required boiling of the tissue sections in $10 \mathrm{~mm}$ citrate buffer, for 10 minutes. The primary antibody was applied for 60 minutes. After incubation the avidin-biotin / peroxidase system was used. The bound peroxidase was visualized by incubation for 
15 minutes with DAB reagent (Diamino-Benzidine). Finally sections were counterstained with Mayer's heamatoxylin (Bancroft and Cook, 1994).

Negative tissue control :

The application of the primary antibody was omitted and replaced with normal mouse serum (Bancroft and Cook, 1994).

\section{Positive tissue control :}

Sections of human placenta known to be positive for i-NOS were processed in the same way as the studied sections (Brancroft and Cook, 1994).

\section{Image analysis of i-NOS immunostaining :}

The immunostained lung sections were examined by Leica Quin 500 image analyzer computer system (England). It was used to measure the area and area percent of positive i-NOS immunoreaction seen as cytoplasmic brown colour.

\section{RESULTS}

\section{Histological results :}

Group I (Control group) :

Examination of HX E - stained lung sections of control rats revealed the normal histological pattern of several, long winding passages (alveolar ducts) which opened along their length into numerous alveolar sacs and alveoli. The lung alveoli in the form of air spaces exhibited normal thickness of their walls (Fig. 1 - a). They were lined with type (I) and type (II) pneumocytes (Fig. 1 - b).

The bronchioles showed normal simple columnar epithelial lining (Fig. 1 - c). The adjacent arteries showed normal thickness of their walls and were surrounded by normal alveoli.

\section{Group II :}

Six rats of this group survived till termination of the experiment. Examination of HX / E-stained lung sections revealed diffuse inflammatory reaction of lung parenchyma (Fig. 2 - a). Marked inflammatory cell infiltrate was present in the interstitium leading to interstitial thickening. The infiltrate composed predominantly of polymorphnuclear leucocytes with eosinophils. Prominent type (II) Pneumocytes could be seen (Figs. 2 - b, c). 
Pink-staining exudate and vascular congestion were observed with extravasations of red blood corpuscles (Fig. 3 - a).

The bronchioles revealed pseudostratification of their epithelial lining. Their lumina contained fibrin strands and shedded cells as well as Polymorphs (Fig. 3 - b).

\section{Group III :}

Only four rats of this group survived for five days after caerulein and Larginine injections. Worsening of the histological picture of lung injury was seen in HX / E-stained sections (Fig. 4 - a). More profuse mononuclear cell infiltrate was present in alveolar walls with markedly thickened alveolar septa. It consisted mainly of clusters of polymorphs and csoinophils. Flooding of alveoli with serotibrinous exudates was evident. Prominence of type (II) Pneumocytes was noticed. The blood vessels were severely congested with extravasations of RBCs showing roleaux appearance (Fig. 4 - b).

The bronchioles were lined with hyperplastic epithelium, their lumina were filled with inflammatory cells, shedded cells and fibrin strands, that led to complete obliteration of some lumina (Figs. 5 - a, b). Peri-bronchiolar aggregates consisting of lymphocytes were also seen (Fig. 5 - c).

\section{Group IV :}

All rats of this group survived till time of sacrifice.

Compared with the previous groups, the histological picture of lung sections revealed normal thickness of most alveolar walls with little fibrinous exudate (Fig. 6 a). Minimal mononuclear cellular infiltrate was present in the interstitium. Slight congestion of pulmonary capillaries was notable (Fig. 6 - b).

The bronchioles showed almost normal epithelial lining with scanty cell infiltrate and reduced peri-bronchiolar lymphocytic aggregation (Fig. 6 - c).

\section{Immunohistochemical results :}

All results were compared with the negative tissue control sections.

Sections from the control group revealed absence of any positive immunostaining with the polyclonal antibody to i-NOS (Fig, 7). Lung sections of group (II) showed positive cytoplasmic immunoreaction within the alveolar epithelium predominantly in pneumocytes type (II). Patchy staining of inflammatory cells was also observed (Figs. 8 - a. b). In group (III), which received L-arginine together with caerulein, positive immuno-staining was seen throughout the lung sections. The 
interstitium, alveolar cpithelium (mainly pneumocytes type II) and bronchiolar exudates were strongly stained (Figs. 9 - a, b, c). However, in group (IV) treated with LNNA, iNOS immunostaining was markedly attenuated and only weak staining of alveolar walls was seen (Fig. 10).

The area percent of $\mathrm{i}$-NOS immunoreaction in the studied groups is shown in Fig. (11).

\section{Pulmonary gas exchange :}

Analysis of arterial blood gases revealed that, the mean $\mathrm{PaO} 2$ in the control group (Group I) was $104.44 \pm 1.02 \mathrm{mmHg}$. Significant deterioration of $\mathrm{PaO} 2$ was found in group (II) which received caerulein injections only and group (III) where L-arginine was co-administered with caerulein. It reached $73.55 \pm 3.07 \mathrm{mmHg}$ and $58.52 \pm 1.01 \mathrm{mmHg}$ respectively.

In contrast, treatment with L-NNA (NOS inhibitor), in group (IV) resulted in an increase of $\mathrm{PaO} 2$ to $94.31 \pm 2.92 \mathrm{mmHg}$ which was non significant compared to the control.

The mean PaO2 in the studied groups are shown in Fig. (12) and Table (1).

In the control group, the mean $\mathrm{PaCO} 2$ was found to be $40.45 \pm 0.69 \mathrm{mmHg}$ and mean $\mathrm{pH}$ was $7.35 \pm 0.11$. Compared with these values, in groups (II) and (III) there were significant increase in $\mathrm{PaCO} 2$ to $48.63 \pm 0.68 \mathrm{mmHg}$ and $54.31 \pm 0.65 \mathrm{mmHg}$ respectively. This was also accompanied with significant decrease in $\mathrm{pH}$ to $7.12 \pm$ 0.19 in group (II) and to $6.98 \pm 0.19$ in group (III). Non significant increase of $\mathrm{PaCO} 2$ or decrease of $\mathrm{pH}$ was noticed in group (IV).

The mean values of $\mathrm{PaO} 2, \mathrm{PaCO} 2$ and $\mathrm{pH}$ in the studied groups are represented in Table (1).

Table 1 : The mean $\pm \mathrm{SD}$ of $\mathrm{PaO}_{2}, \mathrm{PaCO}_{2}$ and $\mathrm{pH}$ in the studied groups.

\begin{tabular}{|c|c|c|c|}
\hline Group & $\mathrm{PaO}_{2}$ & $\mathrm{PaCO}_{2}$ & $\mathrm{pH}$ \\
\hline Group I (control) & $104.44 \pm 1.02$ & $40.46 \pm 0.69$ & $7.35 \pm 0.11$ \\
\hline Group II & $73.55 \pm 3.07^{*}$ & $48.63 \pm 0.68^{*}$ & $7.12 \pm 0.19^{*}$ \\
\hline Group III & $58.52 \pm 1.01^{*}$ & $54.31 \pm 0.65^{*}$ & $6.98 \pm 0.19^{*}$ \\
\hline Group IV & $94.31 \pm 1.03$ & $42.11 \pm 0.75$ & $7.26 \pm 0.06$ \\
\hline
\end{tabular}

*Significant difference compared to control $(P<0.05)$. 

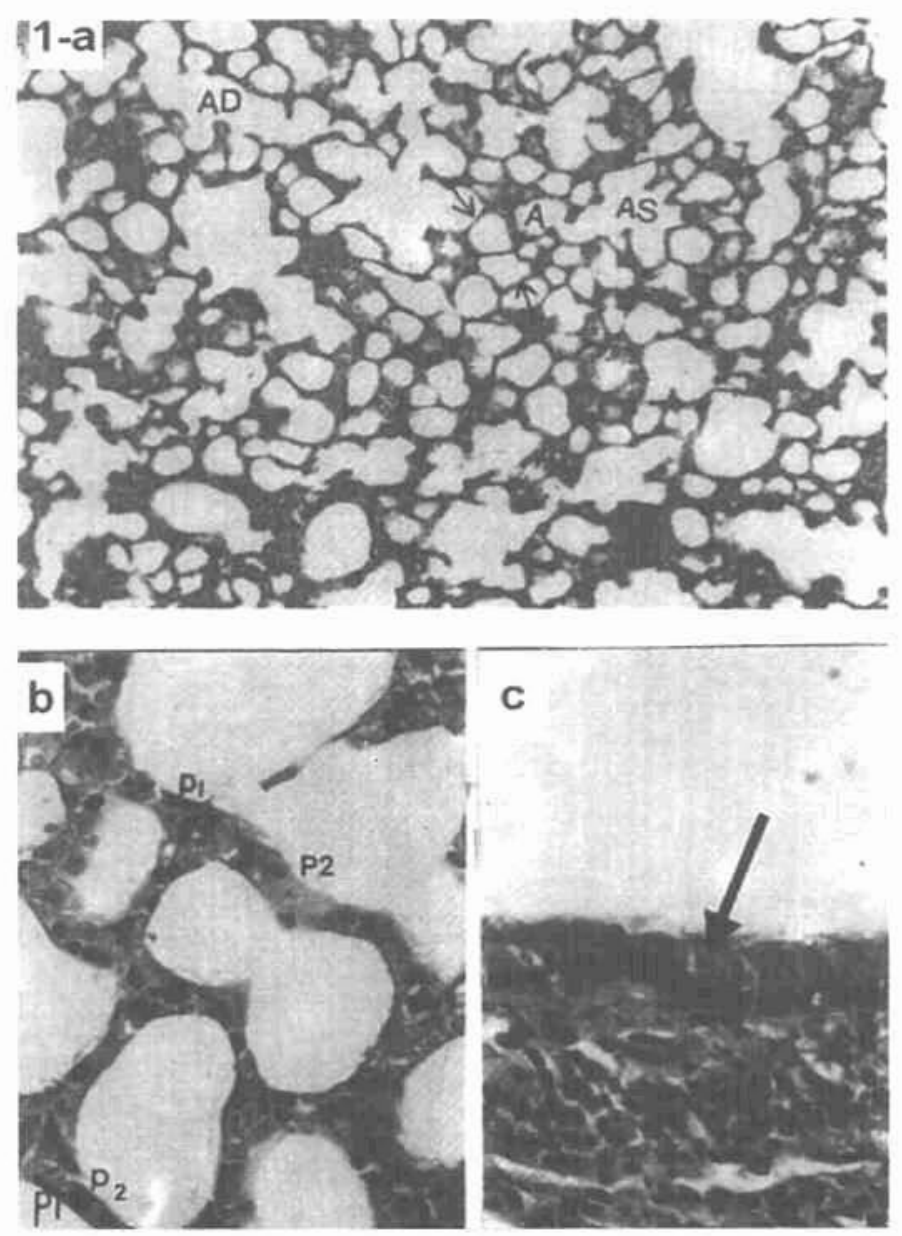

C

Fig. (1) :Photomicrographs of sections in lungs of control rats showing :

a) Alveolar ducts (AD) with numerous alveolar sacs (AS) and alveoli (A). Normal alveolar septa (arrows) between adjacent alveoli.

(Hx. \& E.; x 100)

b) Epithelial lining of alveoli consisting of flattened type I (p1) and rounded type II (p2) pneumocytes.

c) Simple columnar epithelial lining of bronchioles.

(Hx. \& E.; $x$ 400)

(Hx. \& E.; x 400) 

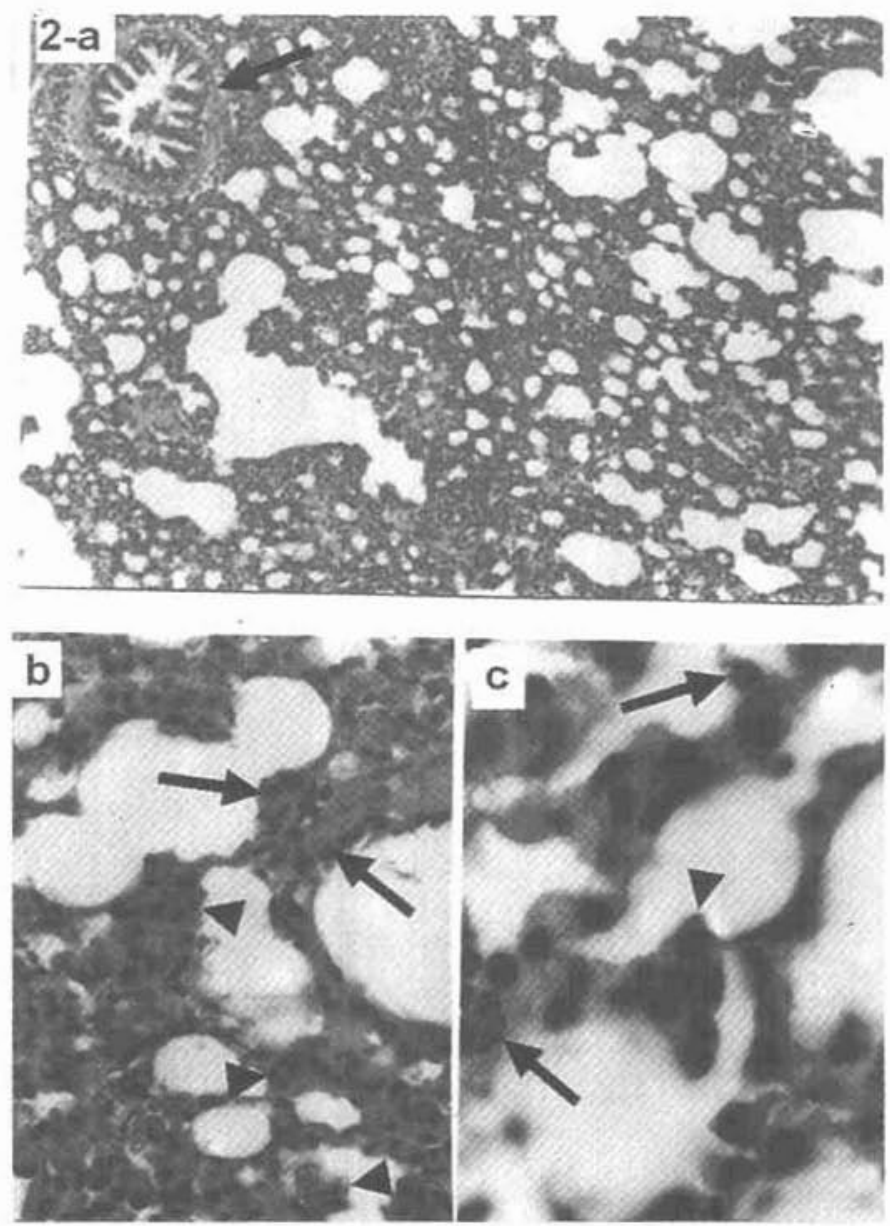

Fig. (2) :Photomicrographs of sections in lungs of cacruleininjected rats (group II) showing :

a) Diffuse inflammatory reaction of lung parenchyma. A bronchiole with intra-luninal infiltrate could be seen (arrow).

(Hx. \& E.; x 100)

b) Higher magnification showing thickened alveolar septa with cellular infiltrate (arrows) and prominent type II pneumocytes (arrow heads). seen in the inter-alveolar septa (arrow head).

(IIx. \& E.; x 400)

(Hx. \& E.; $x$ 1000) 


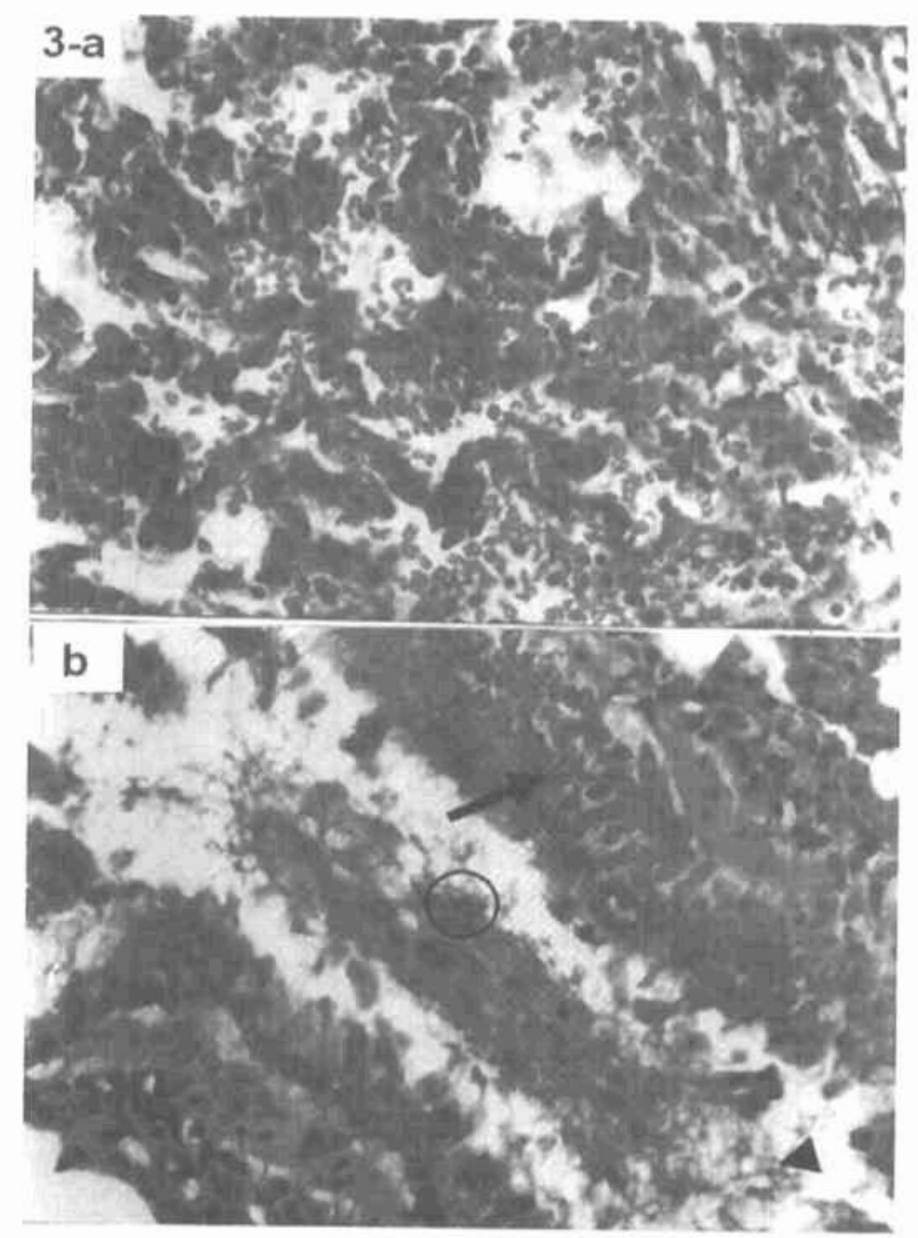

Fig. (3) :Photomicrographs of sections in lungs of caerulein injected rats (group II) showing :

a) Marked congestion and extravasations of many $\mathrm{RBC}$.

(Hx. \& F.; $x$ 400)

b) Pseudostratification of bronchiolar epithelium (arrow) with intra-luminal cell infiltrate of ncutrophils (circled) and fibrin (arrow heads).

(Hx. \& E.; X 400) 

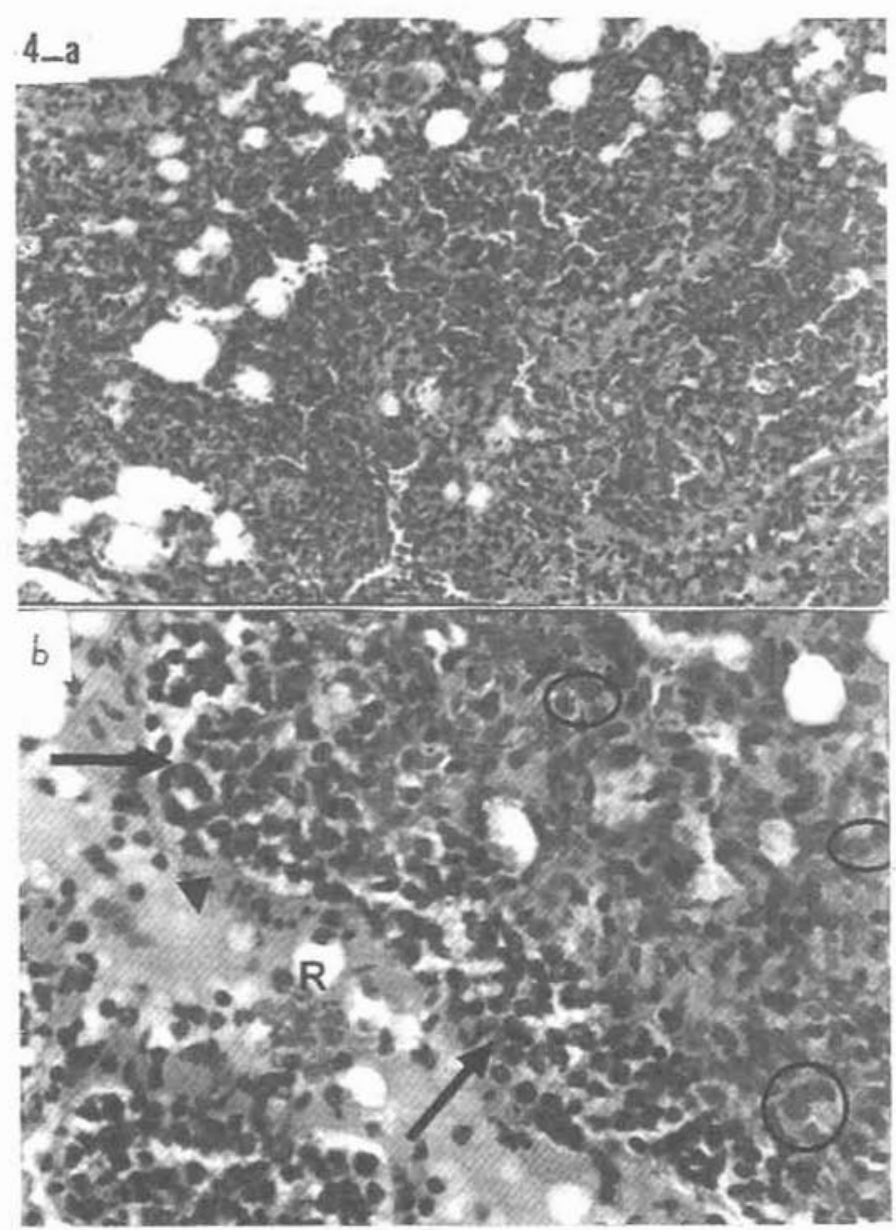

Fig. (4) :Photomicrographs of sections in lungs of group III (caerulein $+\mathrm{L}$-arginine) showing :

a) Loss of normal lung architecture and massive pulmonary hemorthage.

(Hx. \& E.; x 200)

b) Marked mononuciear inflammatory cellular infiltrate (arrows) and Fibrinous exudate could be noted (arrow head). Prominent type II pneumocytes were seen (circled) as well as roleaux appearance of $\mathrm{RBCs}(\mathrm{R})$.

(HIx. \& E; $\times 400$ ) 

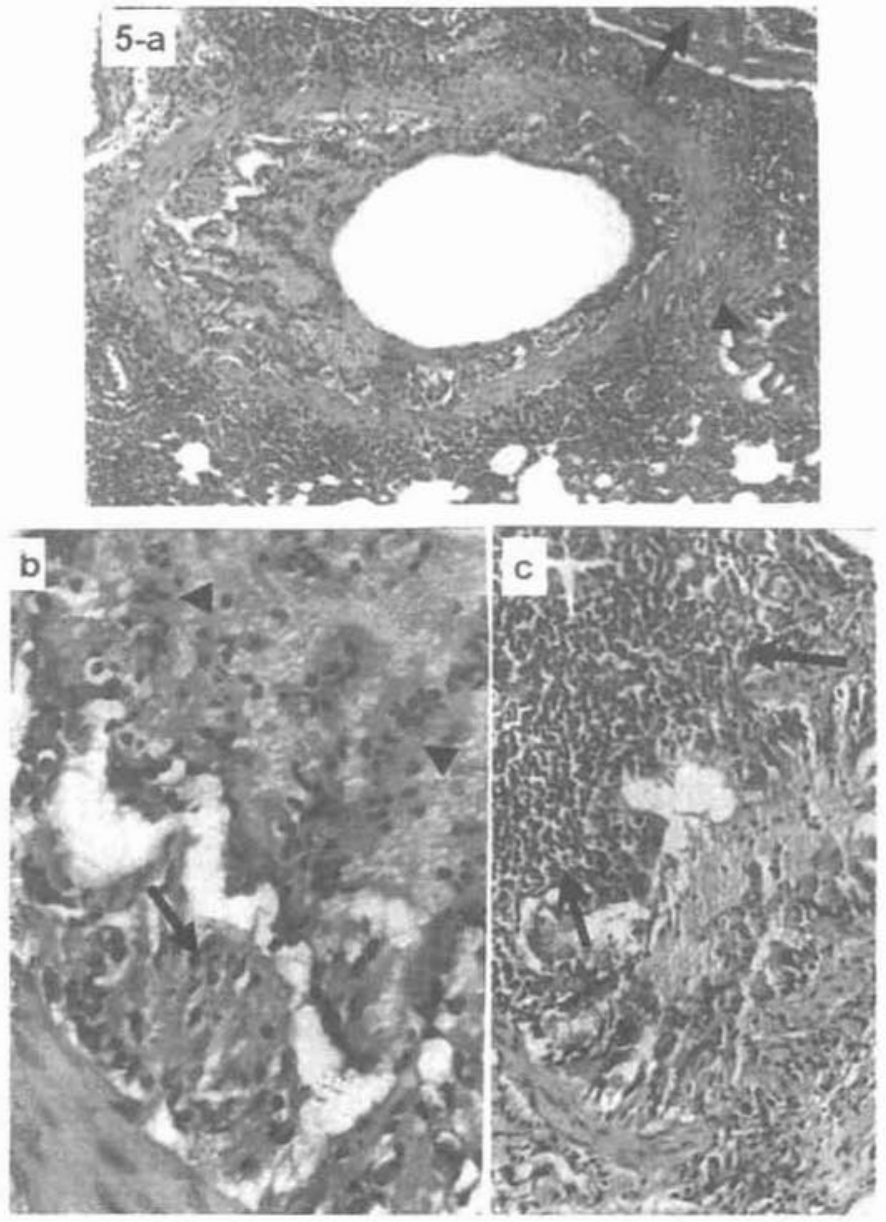

Fig. (5) :Photomicrographs of lung sections of group III (receiving caerulein + L-arginine) showing :

a) A bronchiole with intra-luninal infiltrate and fibrin strands Part of a smaller bronchiole with nearly obliterated lumen (arrow head) and congested blood vessel (arrow).

(Hx. \& E.; x 100)

b) Iligher magnification of a part of the bronchiole revealing hyperplastic epithelial lining (arrow), shedded epithelial cells. and fibrin threads (arrwo heads).

c) Peri-bronchiolar lymphocytic aggregation (arrows),

(Hx. \& E.; $x 400)$

(Hx. \& E.; x 200) 

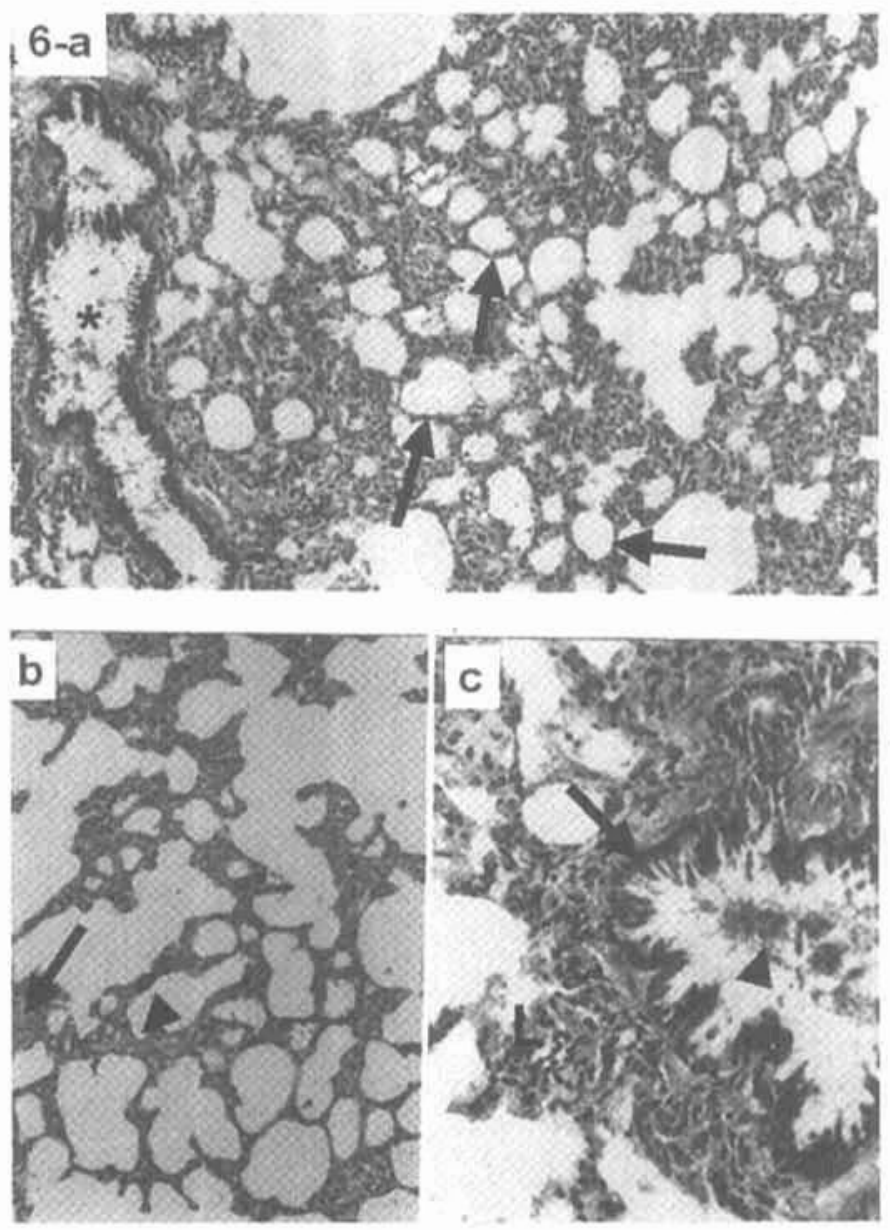

Flg. (6) :Photomicrographs of lung sections of group IV (receiving caerulein + L-NNA injections) showing :

a) Alveolar septa of nearly normal thickness (arrows). A bronchiole with its simple columnar epithelial lining could be seen (*).

(Hx. \& E.; x 100)

b) Mild congestion of pulmonary capillaries. (arrows).

(Hx. \& E.; $x$ 100)

c) A bronchiole with reduced both peri-bronchiolar lymphocytic aggregation and intra-luminal infiltrate.

(Hx. \& E.; x 200) 


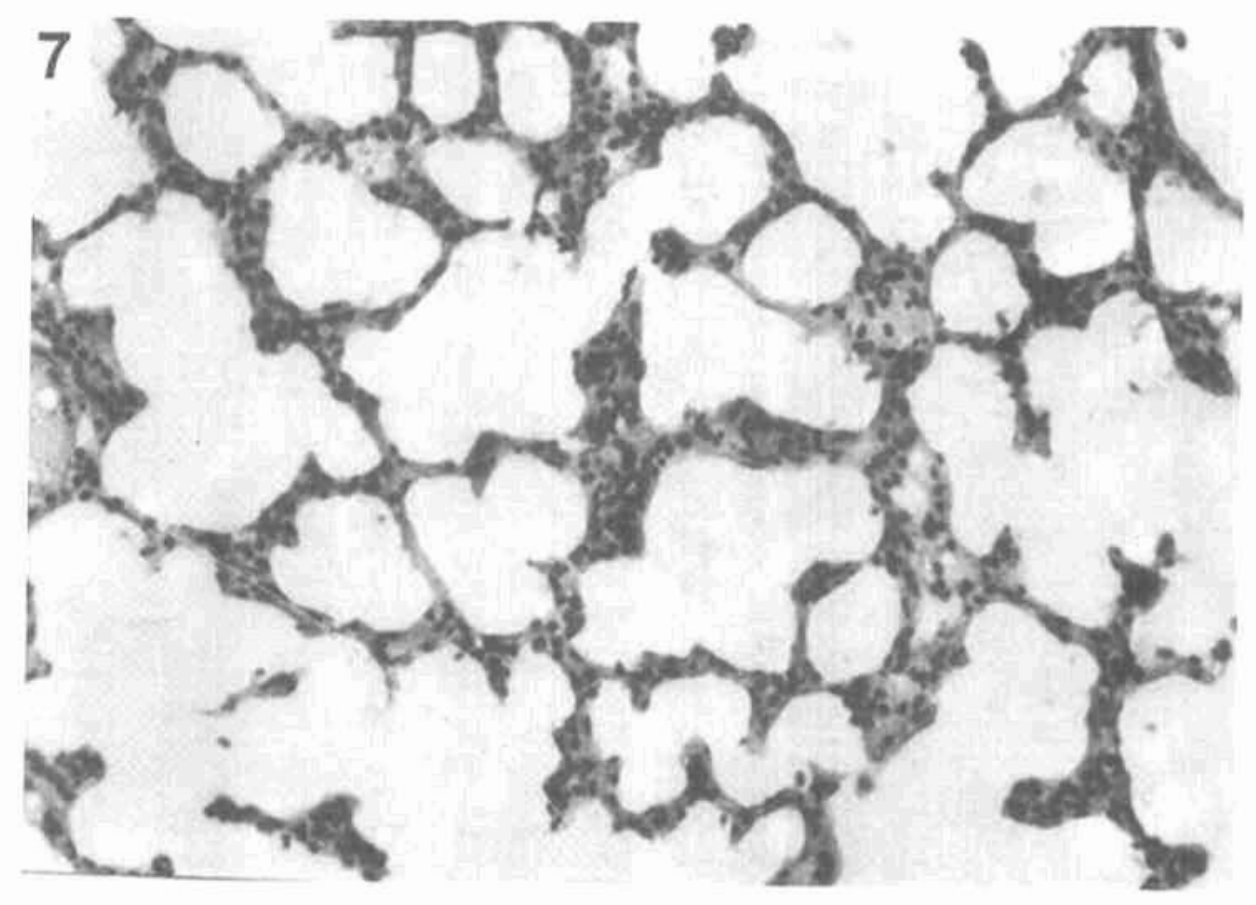

Fig. (7): A Photomicrograph of lung sections of control rat immunostained with i-NOS antibody
revealing negative immunostaining. 

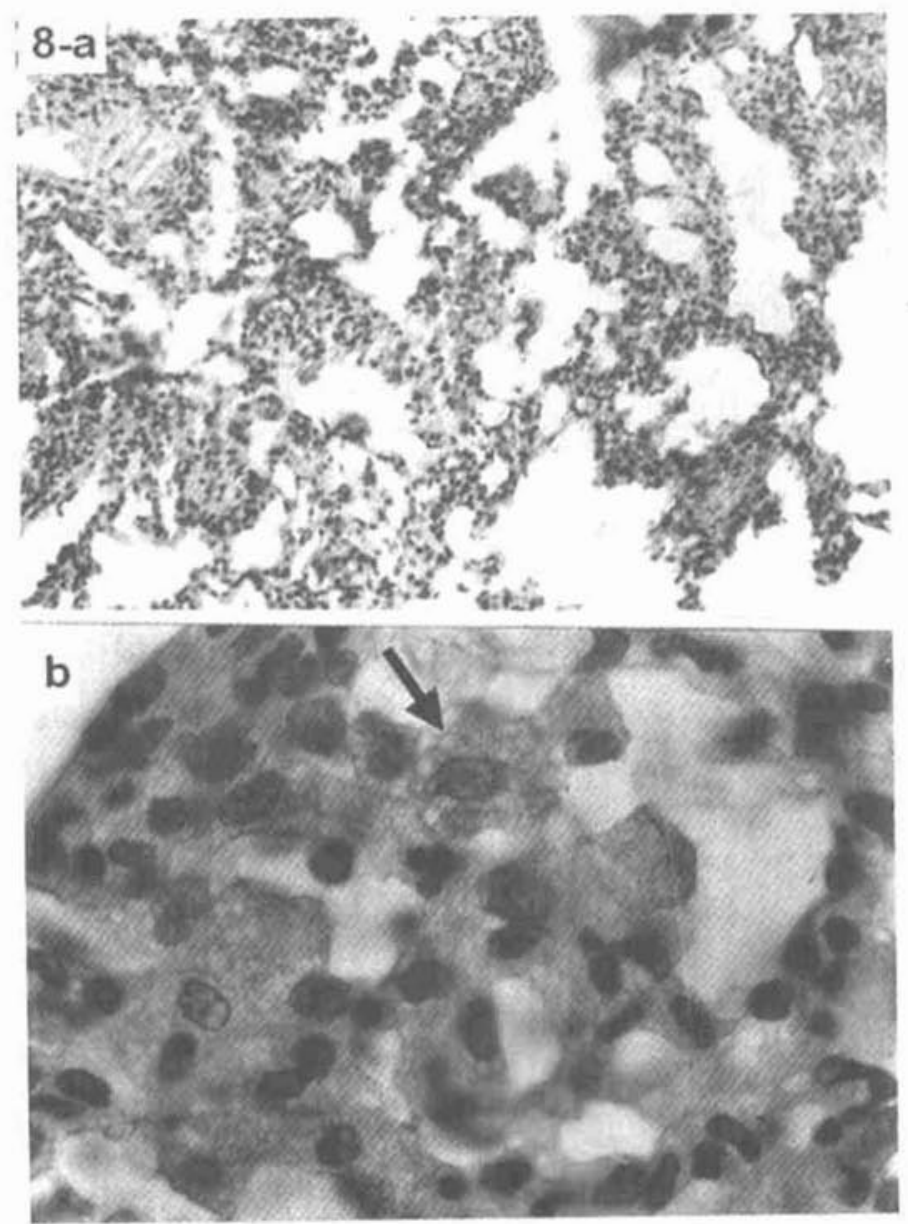

Fig. (8) :Photomicrographs of lung sections of group II immunostained with $\mathrm{i}-\mathrm{NOS}$ antibody showing :

a) Positive immunoreaction within alveolar epithelium as well as some inflammatory cells.

(x 200)

b) Cytoplasmic immunoreactivity within pneumocytes type II (arrow). 

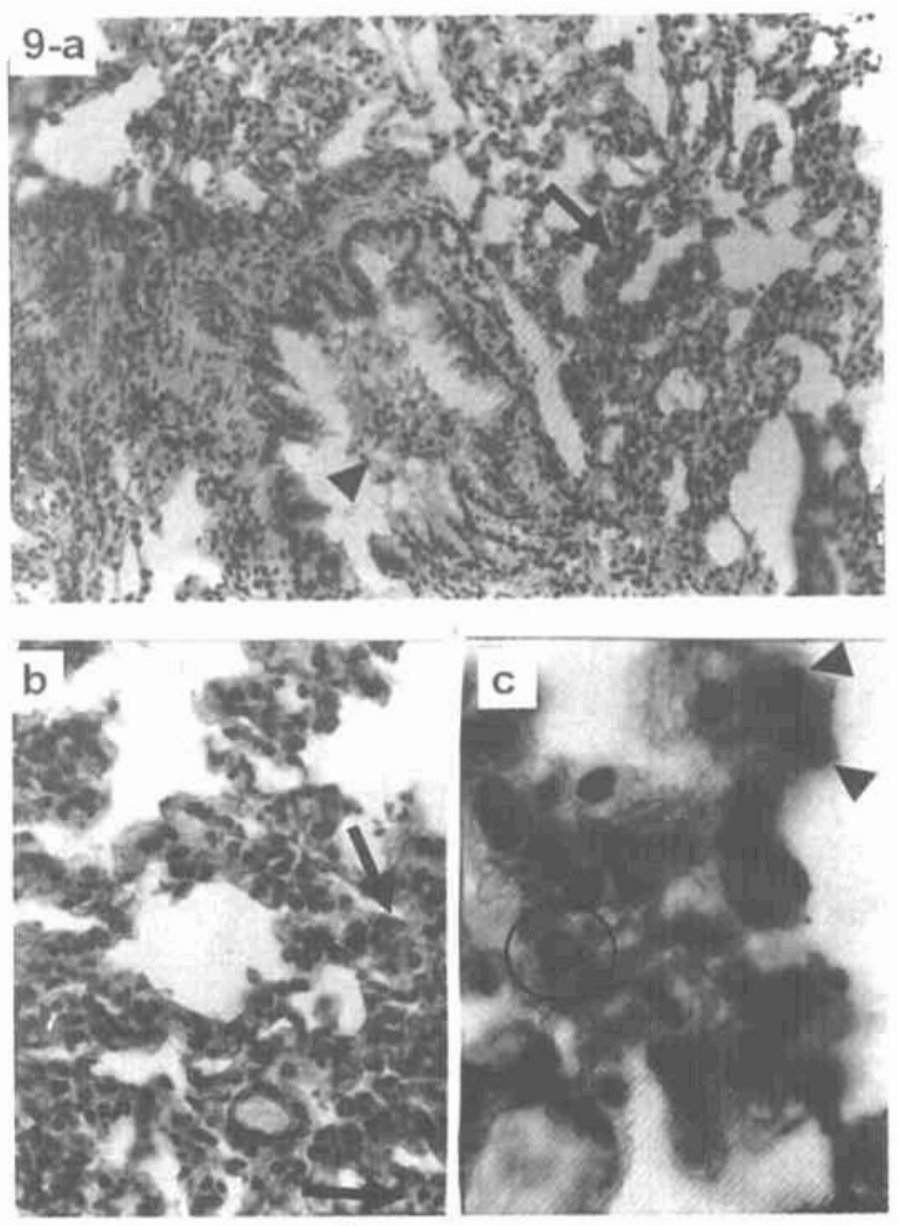

Fig. (9) :Photomicrographs of i-NOS immunostained lung sections of group III showing :

a) Widespread positive reaction throughout lung section, the interstitium (arrows) and intra-bronchiolar infiltrate (arrow heads).

(x 100)

b) Positive i-NOS immune reaction within pneumocytes type II (arrows).

$(x 400)$

c) Positive cytoplasmic staining within Pneumocytes type II (arrow heads) and an eosinophil (circled).

$(x$ 1000) 


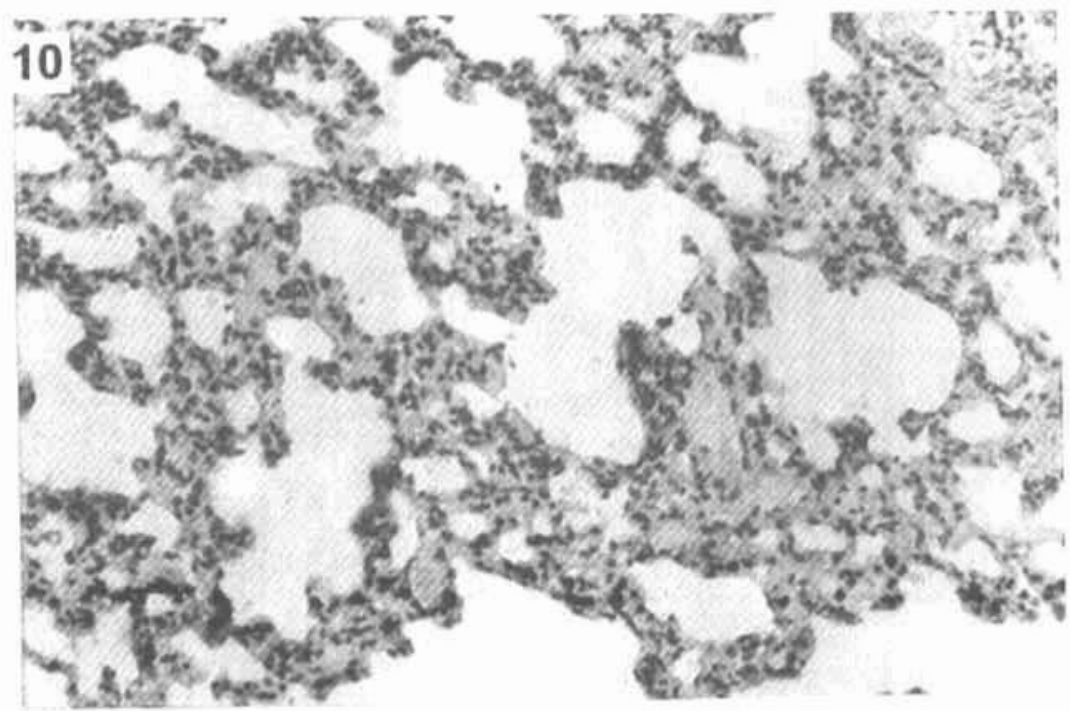

Fig. (10) : A photomicrograph of i-NOS immunostained lung section of group IV showing very weak staining within alveolar walls.

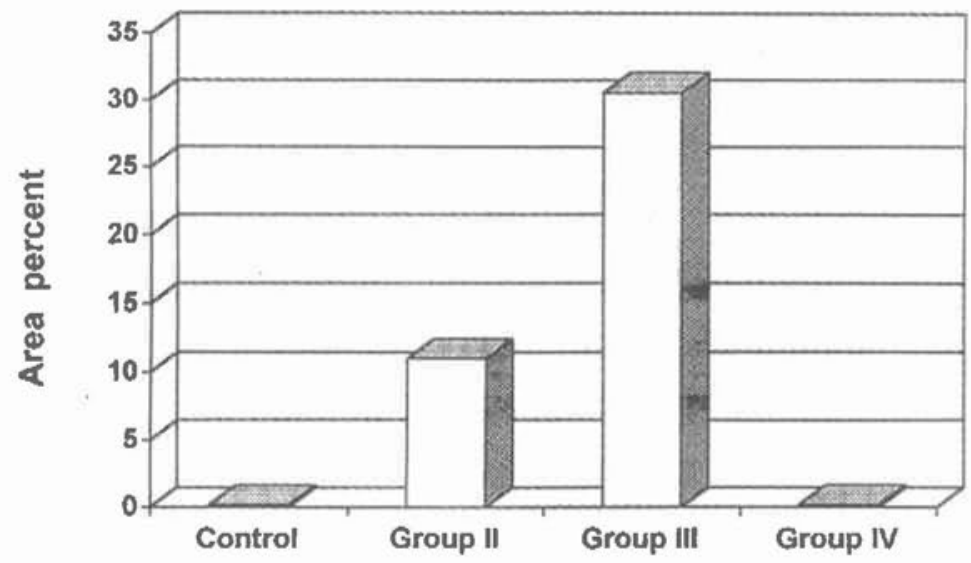

Fig. (11) :Mean area \% of i-NOS immunoreaction in the studied groups. 


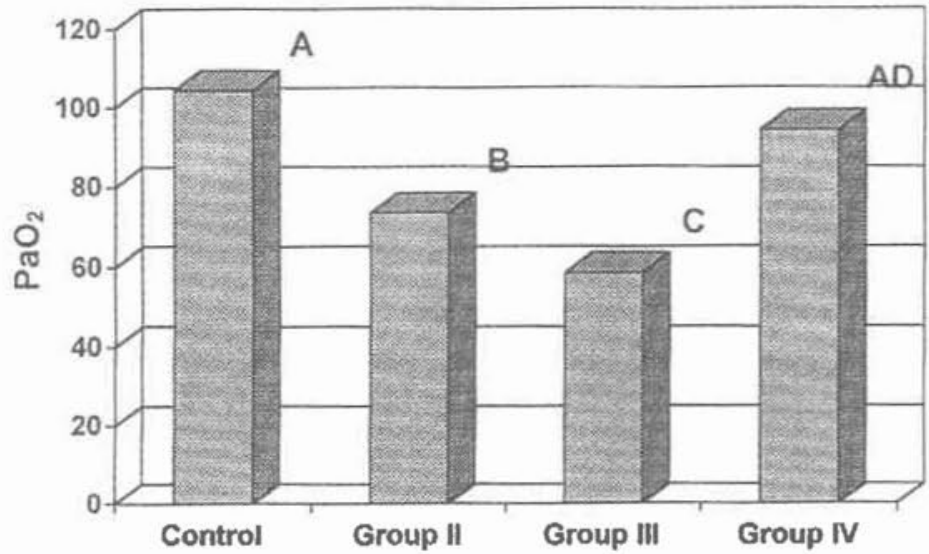

Fig. (12): Mean $\mathrm{PaO}_{2}$ in the studied groups.

Groups not sharing a letter are significantly different from each other $(\mathrm{P}<$ 0.05)

\section{DISCUSSION}

In the present work an experimental model of endotoxaemia-induced lung injury was prepared by subcutaneous injections of caerulein. The administration of caerulein results in pancreatitis associated with a significant lung injury through the release of mediators into the blood that induce within the lung the chronological expression of macrophage inflammatory peptide-2, tumor necrosis factor-alpha and intercellular adhesion molccule-1 (Frossard et al., 2002).

In human medicine, this stage of lung disease is frequently referred to as adult respiratory distress syndrome (ARDS) which is characterized by acute onset of diffuse and severe inflammatory reaction of lung parenchyma resulting in protein rich exudative oedema. These histopathological changes are accompanied by arterial hypoxaemia, abrupt increase in the $\mathrm{PaCo} 2$ (may be decreased in the early stage of ARDS due to hyperventilation) and a corresponding decrease in pH (Meduri et al., 1991).

It had been shown that caerulein injections in group (II) resulted in diffuse inflammatory reaction of lung parenchyma with sequestration of leucocytes mainly polymorphs and thickening of alveolar walls, associated with hypoxaemia $(\mathrm{PaO} 2$ $73.55 \pm 3.07 \mathrm{mmHg}$ ) and acidosis. Co-administration of L-arginine (NO precursor) led to worsening of the lung architecture with more severe hypoxaemia $(\mathrm{PaO} 2$ 
$58.52 \pm 1.01 \mathrm{mmHg}$ ) and acidosis. On the other hand, treatment with L-NNA (NO inhibitor) attenuated these changes to a great extent and resulted in increased $\mathrm{PaO} 2$ to $94.31 \pm 2.92 \mathrm{mmHg}$.

It was reported by Numata et al. (1998) that in sepsis, loxic products activate systemic host defenses including, neutrophils, monocytes, macrophages and endothelial cells that produce toxic host mediators such as cytokines, kinins and Nitric oxide (NO). They also stated that neutrophils have been implicated specifically in the pathogenesis of most cases of human sepsis. Consisted with this report, in the present study neutrophils accumulated in the interstitium of lung with induction of sepsis and treatment with NOS inhibitor attenuated the neutrophil sequestration.

This also goes with preliminary data from ongoing clinical trials which indicate that inhibitors of NOS activity exert beneficial effects in septic shock (Thiemermann, 1997). Also, in several animal models of inflammation, a selective inhibitor of i-NOS, N-iminocthyl L-lysine suppressed the infiltration of inflammatory cells (Wolkow, 1998).

It was found that exogenous nitric oxide clicits chemotaxis of neutrophils (Numata et al., 1998). Thereforc, attenuation of neutrophil infiltration may be explained by inhibition of NO production. Beckman et al. (1992) reported that largc amounts of NO Produced by i-NOS induction interacts with oxygen free radicals derived from neutrophils and macrophages to form peroxynitrite which is a potent and versatile oxidant that can attack many types of biologic molecules.

On the other hand, Liu et al. (2001) concluded that inhibition of NO synthesis in a rat model of acute lung injury induced by hepatic ischemia-reperfusion, not only augments ischemic liver injury but also enhances the systemic inflammatory responsc and exacerbates remote lung injury. This may be attributed to the different mechanisms of inducing lung injury.

The inflammatory reaction in the lung was associated with pulmonary congestion with consequent presence of $\mathrm{RBCs}$, this may be explained by the fact that nitric oxide stimulates soluble guanyl / Cyclase resulting in increased level of cyclic GMP in lung smooth muscle cells. The gating of $\mathrm{K}^{+}$and $\mathrm{Ca}^{2}$ channels by cyclic GMP binding is thought to play a role in nitric oxide mediated vasodilatation (Weinberger et al., 1999). Also according to Motamen et al. (1998). Nitric oxide's function in vasomotor control, inflammation and signal trans-duction makes it an attractive potential mediator of the capillary leak seen in acutc lung injury.

The immunohistochemical sludy of i-NOS was done to investigate the possible source of NO generation during endotoxacmia. In caerulein injected group the 
alveolar epithelium especially pneumocyts type (II) showed positive reaction. This goes with a previous study done by Toga et al. (2001) they isolated i-NOS and its mRNA as well nuclear factor kappa B (NF, kappa B) from type II cells during lung inflammation. They reported that effects of corticosteroids may be in part through inhibition of both i-NOS and NF, kappa B activation. Treatment with L-arginine, resulted in intense i-NOS immunostaining seen in alveolar epithelium and inflammatory cells. According to Weinberger et al. (1999) nitric oxide is produced by many cell types in the lung. On the contrary Wang et al. (2002) suggested that, the microvascular protein leak in sepsis induced acute lung injury is uniquely dependent on i-NOS in inflammatory cells with no obvious contribution of i-NOS in pulmonary parenchymal cells. It had been found that mice deficient in i-NOS gene were more resistant to endotoxaemia induced lung injury than wild-type mice as reported by Koristof et al. (1998).

The observations of this study suggest that increased intra-pulmonary generation of nitric oxide has an important role in the pathogenesis of endotoxaemia induced-acute lung injury. Pncumocytes type (II) and some inflammatory cells (Polymorphs) are possible sources of endogenous NO production. Accordingly. Nitric oxide synthase inhibitors may be elfective in reversing the lung injury.

\section{SUMMARY}

Respiratory complications are major factors contributing to death in acute toxaemia. They are characterized by complex interactions among cytokines, chemokines, adhesion molecules and leucocytes. Pro-inflammatory cytokines have been implicated in the up regulation of the inducible form of nitric oxide synthase (iNOS) which produces large amounts of nitric oxide (NO).

This study was conducted to investigate the effects of increased or decreased endogenous production of nitric oxide on the course of acute lung injury.

Thirty two adult male ambino rats were uscd. Divided into four equal groups. Group (I) received saline injections and served as control. Acute lung injury was induced in the other three groups by subcutancous injections of caerulein. Group (II) was left untreated. In group (III) L-arginine (NO precursor) was co-administrated with cacrulcin, while group IV was treated simultaneously with L-NNA (NOS inhibitor). Results werc cvaluated using histological and biochemical methods. The histological picture of lung injury was associated with hypoxemia. These changes worsened with the co-administration of L-arginine. Treatment with L-NNA greatly 
improved the condition, as manifested by the microscopic examination of lung sections and through analysis of blood gases. Immunohistochemical study of inducible nitric oxide synthase revealed that pneumocytes type (II) and some inflammatory cells (polymorphs) may be the possible source of endogenous NO production in acute lung injury.

It could be concluded that increased intra-pulmonary generation of nitric oxide by the action of inducible nitric oxide synthase plays a critical role in the pathogenesis of acute lung injury. So it is suggested that i-NOS inhibitors may have a potential in the treatment of acutc respiratory distress syndrome.

\section{REFERENCES}

1. Anderson, W.R. and Thielen, K. (1992) : Correlative study of adult respiratory istress syndrome by light, scanning and transmission electron microscopy. Ultrastruct. Pathol., 16 (6) : 615 - 628.

2. Andrzejewska, A. and Jurkowska, G. (1999) : Nitric oxide protects the ultrastructure of pancreatic acinar cells in the course of caerulein-induced acute pancreatitis, Int. J. Exp. Path., $80: 317$ - 324.

3. Bancroft, J.D. and Cook, H.C. (1994) : Immunocytochemistry. In Manual of Histological Techniques and their Diagnostic Applications. Churchill Livingstone, Edinburgh, London, Madrid, Melbourne, New York and Tokyo, P. 263.

4. Beckman, J.S.; Ischiropoulos, H.; Van der Woerd, C.; Smith, J.; Chen, J.; Harrison, J.; Martin, C. and Sai, T. (1992) : Kinetics of superoxide dismutase and iron catalyzed nitration of phenolics by peroxynitrite. Arch. Biochem. Biophys., $298: 438$ - 443.

5. Bernard, G.R.; Artigas, K.L.; Brigham, J.; Carlet, K.; Falke, L.; Hudson, M.; Lamy, J.R.; Legall, A. and Morris, R. (1994) : The American-European consensus conference on ARDS. Am. J. Respir. Crit. Care Med., 149 : 818 - 827.

6. Frossard, J.I.; Hadengue, A.; Spahr, L.; Morel, P. and Pastor, C.M. (2002) : Natural history of long term lung injury in mouse experimental pancreatitis. Crit. Care Med., 30 (7) : 1541 - 1546.

7. Gelleret, D.; Nussler, A.; Disilvio, M.; Lowestein, R.; Shopiro, S. and Billiar, T. (1993) : Cytokines, endotoxin and glucocorticoids regulate the expression of inducible nitric oxide synthase in hepatocytes. Proc. Natl. Acad. Sci., USA, 90 : $522-527$. 
8. Ischiropoulos, H.; Zhu, L. and Beckman, J. (1992) : Peroxynitrite formation from macrophage-derived nitric oxide. Arch. Bichem. Biophys., 298 : 446 - 449.

9. Koristof, A.; Goldberg, P.; Laubach, V. and Hussain, S.N. (1998) : Role of inducible nitric oxide synthase in acute lung injury. Am. J. Respir. Crit. Care Med., 158 (6) : $1883-1889$.

10. Liu, P.; Xu, B. and Hock, C.E. (2001) : Inhibition of nitric oxide synthesis by L-name exacerbates acute lung injury induccd by hepatic ischemia-reperfusion. Shock, $16(3): 211-217$.

11. Lowenstein, C.J.; Dinerman, J.L. and Snyder, S.H. (1994) : Nitric oxide : a physiologic messenger. Ann. Intern. Med., $120: 227$.

12. Matsuo, N. (1999) : The role of intrapulmonary nitric oxide generation in the development of adult respiratory distress syndrome. Surg. Today, 29 (10) : 1068 1074.

13. Meduri, G.; Belenchia, J.M.; Estes, R.J.; Wundderink, R.G.; El Torky, M. and Leeper, K.V. (1991) : Fibroprolifcrative phase of ARDS : Clinical findings and effects of corticosteroids. Chest, $100(4): 943-952$.

14. Meduri, G.; Eltroky, M. and Winer-Muram, H.T. (1995) : The fibroproliferative phase of late adult respiratory distress syndrome. Semin. Respir. Infec., 10 (3) : $154-175$.

15. Moncada, S.; Palmer, R. and Higgs, E. (1991) : Nitric oxide : physiology, pathophysiology, and pharmacology. Pharmacol. Rev., 43 : $109-115$.

16. Motamen, T.; Miner, T.J.; Starnes, B.W. and Donohue, T. (1998) : Nitric oxie mediates acutc lung injury by modulation of inflammation. J. Surg. Res., 78 (2) : $137-142$.

17. Mould, R.F. (1989) : Introductory Medical Statistics. 2nd ed., Adam Hilger, Bristol, Philadelphia, P.P. 17, 22, 126.

18. Numata, M.; Suzuki, S.; Miyazaw, N.; Miyashita, A.; Nagashima, Y.; Inoue, S. and Okuba, T. (1998) : Inhibition of inducible nitric oxide synthase prevents LPS-induced acute lung injury in dogs. J. Immun., $160: 3031$ - 3037.

19. Palmer, R.M.; Ashtibm, D. and Moncada, S. (1987) : Vascular endothelial cells synthesize nitric oxide from L-argininc, Nature, 333 : 664 - 668 .

20. Thiemermann, C. (1997) : Nitric oxide and septic shock. Gen. Pharm., 29 (2) : $159-166$.

21. Toga, H.; Toba, T.; Ueda, Y.; Yang, G.H.; Okazak, H.; Katsuda, S. and Ohya, N. (2001) : Inducible nitric oxide synthase expression and nuclear factor- 
kappa $B$ activation in alveolar type II cells in lung injury. Exp. Lung Res., 27 (6) : $485-504$.

22. Wang, L.; Patel, M.; Razavi, H.M.; Weicker, S.; Joseph, M.G.; McCormack, D.G. and Mehta, S. (2002) : Role of inducible nitric oxide synthase in pulmonary microvascular protein leak in murine sepsis. Am. J. Resp. Crit. Care Med., 165 (12) ; 1634 - 1639.

23. Weinberger, B.; Heck, D.F.; Laskin, D.L. and Laskin, J.D. (1999) : Nitric oxide in the lung : therapeutic and cellular mechanisms of action. Pharm. Ther, $84(3): 401-411$.

24. Wolkow, P.P.. (1998) : Involvement and dual effect of nitric oxide in septic shock. Inllamm. Res., 47 (4) : 152 - 158. 


\section{المخص العريب

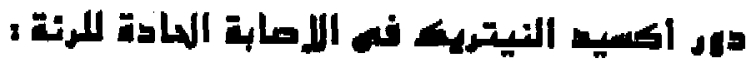 \\ تراست هسترلوبيته بيركيمياتية}

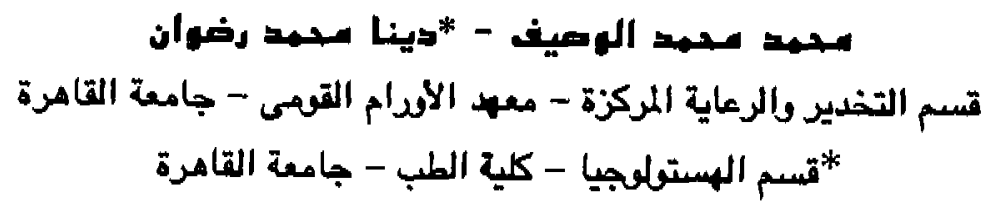

تعتبر المضاعفات التنغسية من أمه الأسباب المؤدية اللوفاة فى حالات سمية الام

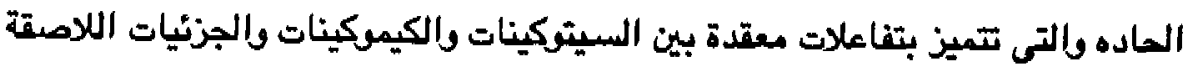

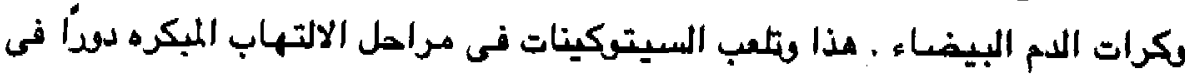

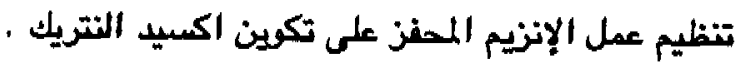

أجريت مذه الدراسة لفحص تأثير زيادة أو نتص انتاج اكسيد النتريل داخليًا على تطود الإميابة الصادة للرئة .

تسـمت ذكور الفئران البيضـاء إلى أريعة مـهموعات متسـاوية ( 1 فنـران )

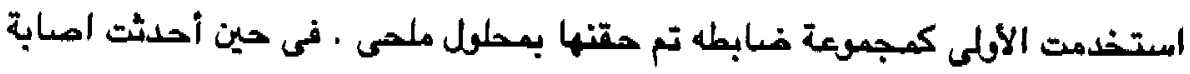

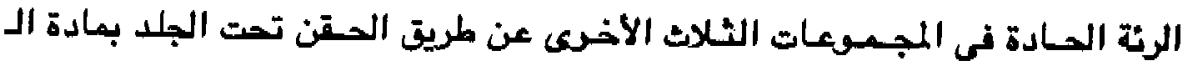

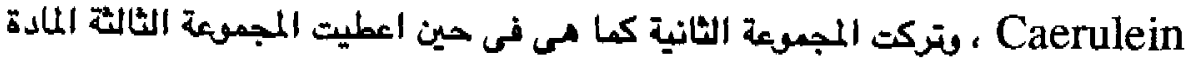

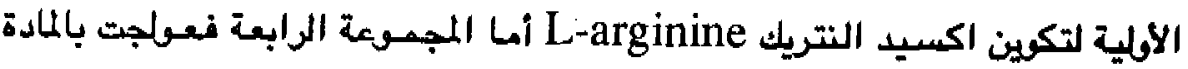
المثبطة للإنزيم المكن لاكسيد النتريك L-NNA ، وتم تتيسيم آثار مذه المعامسلات

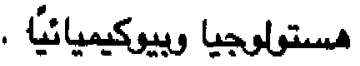

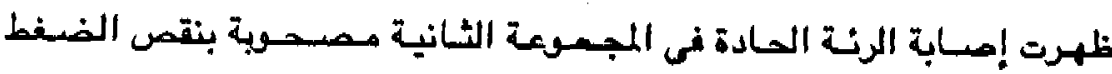

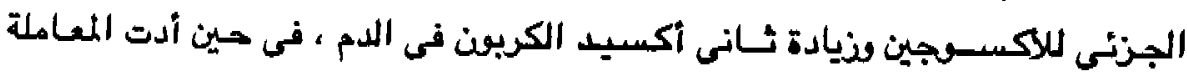




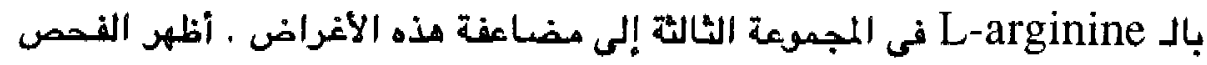

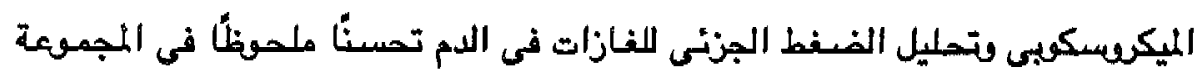

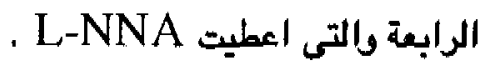

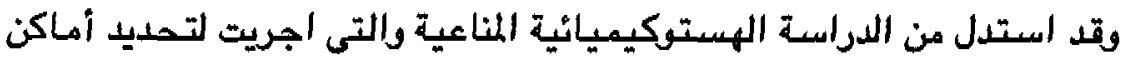

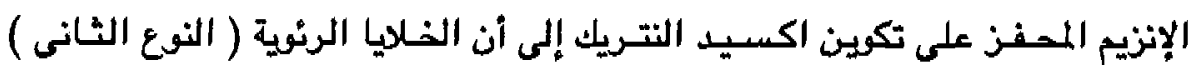

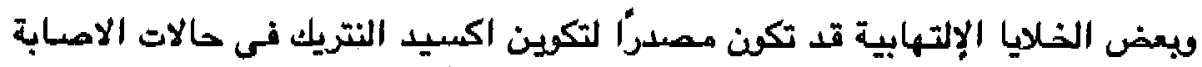

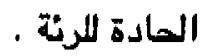

وتثير نتائج هذا البحث إلى أن الزيادة الداخلية لإفراز اكسيد النتريك فى المئة

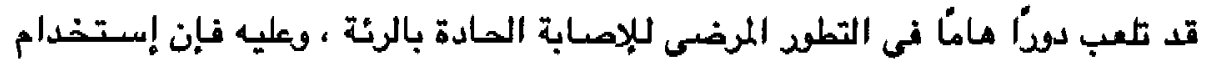

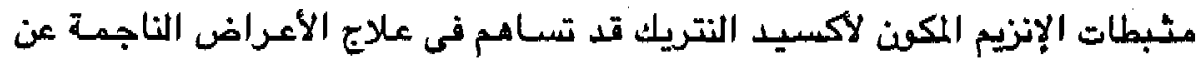

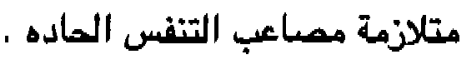

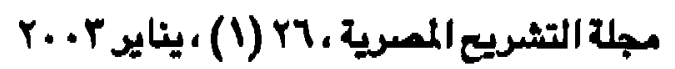

